\title{
Evidence of Bat Sacrifice in Ancient Maya Cave Ritual
}

\author{
James E. Brady \\ Department of Anthropology, California State University Los Angeles, Los Angeles, CA, USA \\ Email: jbrady@calstatela.edu
}

How to cite this paper: Brady, J. E. (2019). Evidence of Bat Sacrifice in Ancient Maya Cave Ritual. Archaeological Discovery, 7, 84-91.

https://doi.org/10.4236/ad.2019.72006

Received: February 11, 2019

Accepted: March 29, 2019

Published: April 1, 2019

Copyright $\odot 2019$ by author(s) and Scientific Research Publishing Inc. This work is licensed under the Creative Commons Attribution International License (CC BY 4.0).

http://creativecommons.org/licenses/by/4.0/

\begin{abstract}
Excavations conducted in Naj Tunich, Petén, Guatemala encountered a number of slabs of speleothem curtains that were used as altars. Two of these contained bat skeletons suggesting that bats had been sacrificed as part of ceremonies carried out in the cave. A review of the archaeological literature documents that remains of bats has been reported in burials, caches, and constructions. Naj Tunich, however, is the first instance of sacrifice occurring in a cave which raises the problem of distinguishing between cultural as opposed to natural deposition. A series of propositions are advanced for dealing with the issue.
\end{abstract}

\section{Keywords}

Maya, Cave, Bat, Sacrifice, Ritual, Naj Tunich

\section{Introduction}

Maya cave archaeology as a self-conscious area of investigation dates only to the end of the last millennium (Scott, 2012). The rapid expansion of the field since that time has produced an impressive corpus of data concerning Maya ritual and, in the process, field archaeologists involved in cave studies have begun to more critically examine their artifact assemblages. Classes of material not previously collected have been shown to have ritual significance (Brady et al., 1997; Brady \& Prufer, 1999; Brady \& Rissolo, 2006; Halperin et al., 2003). A similar situation appears to be the case with animal bones where cave investigators, with the notable exception of David Pendergast $(1969,1971,1974)$, have tended not to save and analyze faunal remains. Even where samples have been saved, however, the bones of species that inhabit or frequent caves are often not given close consideration since one cannot rule out their being naturally deposited (Luther, 1974: p. 63; Pohl, 1983: p. 90; Pollock \& Ray, 1957: p. 642; Savage, 1971: p. 83). 
While it is recognized that natural deposition is a problem, attention needs to be focused on the implications of overlooking locally occurring species from the analysis of ritual sites. It may be that species inhabiting ritual sites are precisely those selected for utilization. Lévy-Bruhl (quoted in Eliade, 1958: p. 367) observes that, "To these natives, a sacred spot never presents itself to the mind in isolation. It is always part of a complexus of things which includes the plant or animal species which flourished there at various seasons...". This very point has been documented in the ethnographic record for the Maya area where plants and animals found near cenotes [a cave feature] are associated with the rain god and the plants are those preferentially selected for ritual use (Redfield, 1941: p. 117). The problem for cave archaeologists is that their field or analytical procedures might tend to exclude from consideration the remains of those species which are potentially most intimately associated with cave ritual. This paper will offer evidence that this is the case with respect to bat remains.

\section{Bat Utilization at Naj Tunich}

Naj Tunich, a large cave site located in southern Peten, Guatemala, was first reported in 1980 (Figure 1). Archaeological investigation was carried out between 1981 and 1989 (Brady, 1989). Clear evidence of bat utilization was recovered during stratigraphic excavations conducted in 1988 on the Balcony, a highly modified area of the cave entrance. By filling and leveling behind several dozen retaining walls, the Maya created a two-tiered platform that served as the cave's central ceremonial stage (Figure 2). In one excavation at the base of the retaining walls, a large slab of stalagmitic curtain was found set on top of a number of rocks to form an altar. The horizontally set piece of formation was flat except for a naturally occurring trough which ran the length of the stone. This trough was completely filled with charcoal, presumably from burning copal. While not containing faunal remains, this find was important in establishing the use of this type of formation as an altar top and, therefore, special care was taken when similar pieces were found in an excavation on the second level of the Balcony. An excavation unit opened in the cave floor just below Structure 1 found a piece of that formation with the headless skeleton of a bat in the trough (Figure 3). To recover all of the bones, the formation was removed and the dirt from the trough was carefully passed through a fine sieve. While the location of the bones in the trough is suggestive of cultural utilization, the possibility, however unlikely, was recognized that the bat could have died of natural causes and fallen into the trough.

The removal of the formation uncovered a second, similar piece with the trough facing downward. When this formation was removed, a second, complete, bat skeleton was revealed in the soil impressed along the trough. While the first skeleton might have been a highly unusual example of natural deposition, the second in the downward-facing trough removes any doubt of its cultural origin. 


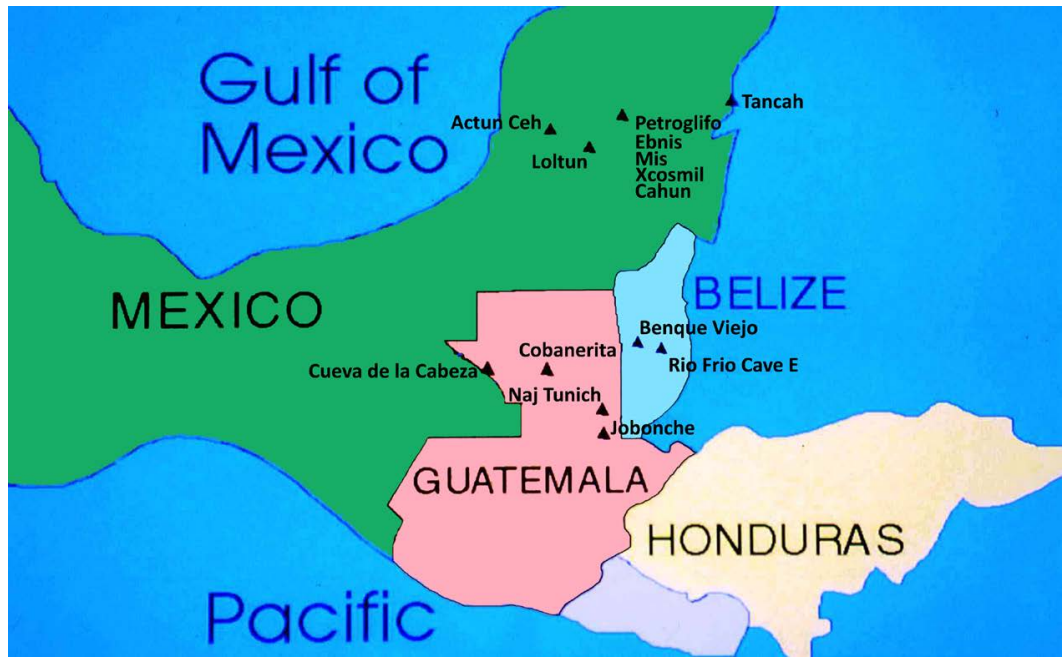

Figure 1. Map of Central America showing the location of Naj Tunich in Guatemala.

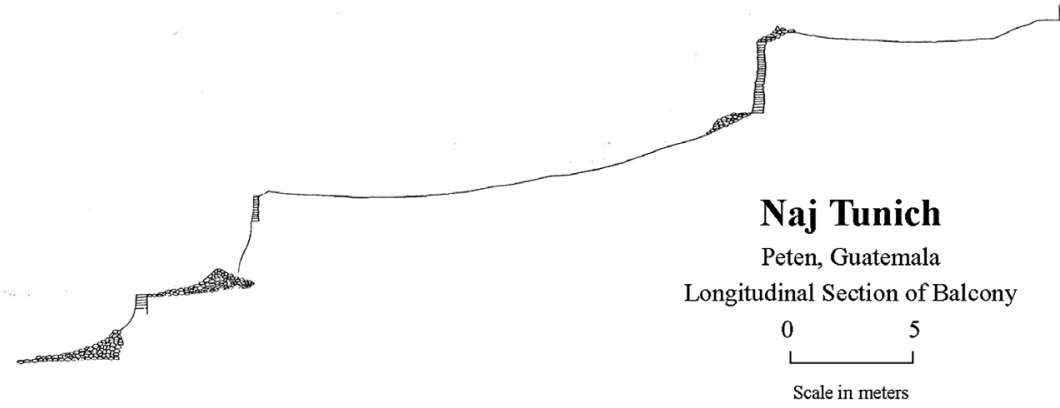

Figure 2. Cros section view of the balcony.

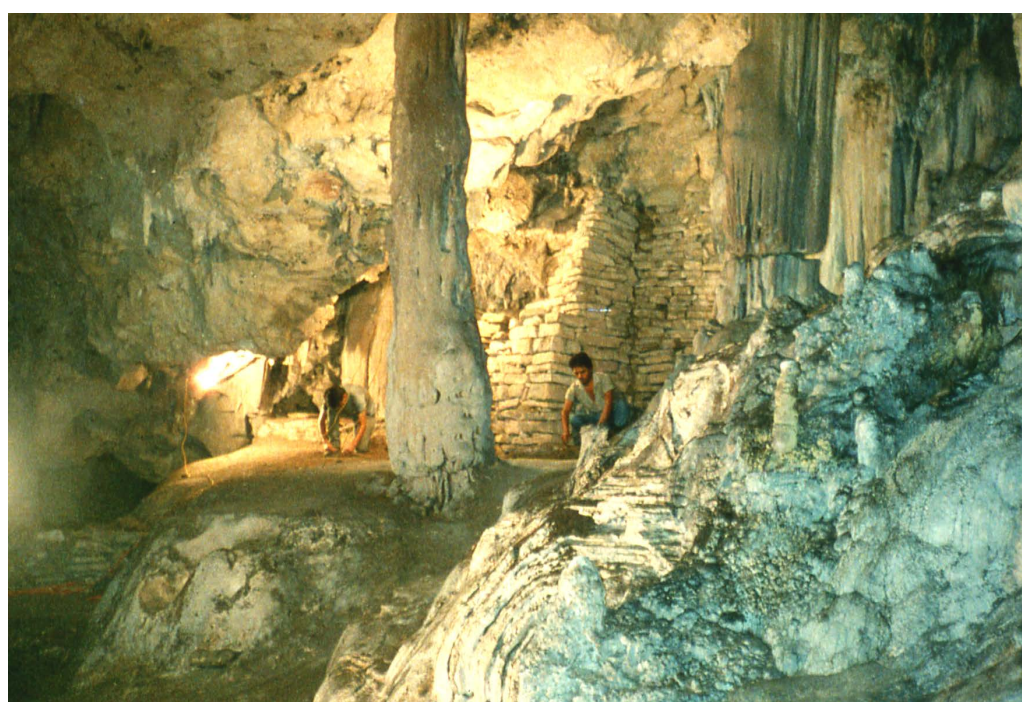

Figure 3. The bat skeletons were found in excavation on the floor below Structure 1 .

Actually, these discoveries culminated several days of discussion over the possibility of a cultural use of bats engendered by the recovery of a far larger quan- 
tity of bat bone along use-floors than in pre-cultural levels in another excavation unit. This is exactly the opposite of what one would expect. On our initial visit to Naj Tunich, it was noted that our presence scared away bats living in the tunnels and they did not return the subsequent day. The posting of a guard shortly after this was enough to keep the bats from returning. Thus, even a moderate use of the cave in ancient times should have been sufficient to cause the bats to relocate.

During ceremonies conducted in Naj Tunich by Q'eqchi' Maya in 1988 and 1989, huge quantities of copal incense were burned, filling the entire entrance chamber with clouds of thick black smoke. Such burning appears to be a common feature of Maya ceremonies, so much so, that the K'iche' refer to rituals as "burnings" (Cook, 1986: p. 139). During the archaeological survey at the site, it was noted that many of the ceiling formations had been smoke blackened in ancient times so it is suspected that ancient ceremonies would have regularly filled the entrance in the same way as modern ceremonies. Once again, it is unlikely that bats would have remained in the presence of such pollution. Finally, the ceilings above our excavations were checked for evidence of bat marking which might indicate that the area had been used for perching since most naturally occurring skeletons would be deposited below such an area. None were found and it should be noted that all the bats encountered on our first visit had been roosting in the tunnels rather than the entrance. For all these reasons, the presence of large quantities of bat bones along use-floors appears anomalous and suggests cultural utilization.

\section{Archaeological Distribution of Bat Remains}

Although bat remains are infrequently reported, they are not unknown in the archaeological literature. Large quantities of bones from two species of bat and several species of rat were found in the excavation of a series of altars in Temple E-II at Uaxactun (Ricketson \& Ricketson, 1937: p. 55). Mixed with the bones were over 70 fragments of jade as well as flint and shell in a matrix of fine black soil. Associated with the altars was Cist C-8 containing two ceramic vessels placed lip to lip inside of which were to two obsidian lancets that the authors suggest were used for sacrificing the animals. A vampire bat skull was found in Burial A33 (Smith, 1950: p. 98) at the same site along with the bones of a rat, mouse, shrew and a small bird. Skull fragments of an unidentified specie of bat was also recovered in Burial E4 along with bones of a bird and the skull of a rodent (Ricketson \& Ricketson, 1937: p. 141).

The skull of a leaf-nosed bat was found in Cache C5 beneath a bench at San Jose, Belize (Thompson, 1939: pp. 189-190). The cache contained a tubular bone ornament, a jade pebble, a pottery spindle whorl and a human tooth. The bones of bats and birds were also found in a cache at Palenque (Fernandez, 1943: p. 55). The bones were deposited in two cylindrical vessels with sherd lids so these are clearly not intrusive. In addition to the bones were fragments of jade and 
"anthropoid extremities". Two bat skulls were recovered from a burial at San Gervasio but these were treated as intrusive (Hamblin, 1984: p. 162). Ignacio Bernal (1949: p. 95) investigated a number of tombs in Coixtlahuaca, Oaxaca that were so well sealed that there was no dust on the floors. He found quantities of bat skeletons in vessels that had been left as funerary offerings.

Willian Coe (1990: p. 673) discovered bat bones along will bones of deer, dog, cottontail, toad, lizard, snake, tortoise and 150 bird bones in a Preclassic chultun in the bedrock located beneath the centerline of several later structures in Tikal's North Acropolis. In addition, 200 Pomacea and 400 animal teeth were recovered. Twenty-five human bones were also found. Based on the unusual assemblage Coe (1990: p. 674) suspected that the chultun may have had an "esoteric" function.

Kitty Emery (2004) lists bat remains from the Cueva de los Quetzales among the "sacred animals" found in the faunal assemblage. Although she acknowledges that the species may have been utilized outside the cave and deposited there only at the conclusion of the ritual, her analysis frequently mentions the "underworld" association of the species in attempting to link them to the cave context. The archaeologists who excavated the site, however, clearly see all the material from the deposit as being utilized in rituals conducted in the central plaza of the site of Las Pacayas before being dropped down an opening in the plaza into the cave below (Brady \& Rodas, 1995: pp. 30-31).

\section{Discussion and Conclusion}

While the proposal that bats were utilized for ritual purposes is not new, the idea does not appear to be widely accepted. Based on the cases available to him, Coe (1959: p. 64) states that, "The practice of sacrificing birds (and bats) and subsequently depositing them as votive offering evidently was established widely and persistently among the Maya". Given the fact that Coe produced fewer examples of bat offerings than cited above, his assertion was more provocative than convincing. Pohl (1983: p. 85) also raises the possibility that bats, along with rats and birds that live in caves, were used in ritual because of their cave association. Our data support the proposition that bats were considered by the ancient Maya to be a ritual fauna and suggest that they may have played an important role in cave ritual.

Brady and Coltman (2016) have recently discussed the meaning of bat depictions in Maya iconography, ethnohistory and ethnography. While the range of possible meanings is interesting, none show a bat actually being sacrificed and so do not provide direct information about the role of bats in the rituals documented at Naj Tunich. Lopez Medel's Relación of 1612 mentions that a woman to be sacrificed in the Sacred Cenote at Chichen Itza was instructed in what to ask for when meeting the gods (Tozzer, 1941: p. 223). In this way, the victim was both an offering to the gods and a messenger from the society. We find this to be a very reasonable model to apply to bat sacrifice. Brady and Coltman (2016: pp. 
231-233) see bats as frequently being in the role of messengers for earth deities. Tozzer (1941: p. 180, note 948) notes that sacrifice is particularly prominent in petitions for rain and the Maya consider rain to be a terrestrial phenomenon produced in caves (Morris, 1986: p. 57; Vogt, 1969: p. 302). Thus, bats become the ideal sacrifice/messenger for rituals carried out in caves because of the animal's ability to navigate cave passages in complete darkness.

The bat remains previously documented in archaeological contexts tend to be recovered from caches, burials and constructions. They were noted simply because they were so "out of place". The current work is the first to offer solid evidence of utilization within caves. Utilization of bats within caves presents an obvious problem for archaeologists excavating in caves and analysts dealing with cave faunal assemblages who must now attempt to determine when or to what extent the remains are natural or cultural. At a minimum, archaeologists need to make a detailed examination of the physical location of excavation units in relation to current bat traffic and roosting areas. The presence or absence of bat bone on the surface should also be noted before excavation is begun. Such steps will provide data which will allow analysts to eliminate the most obvious cases of naturally deposited bone. Most importantly, careful control of archaeological context during excavation is essential.

The problem for the analyst is even more difficult. Certain areas may reflect natural deposition while others cultural utilization, so analyses which fail to separate one unit from another may obscure potentially significant patterns. On the other hand, dealing with individual lots generally reduces bone counts to the point where the numbers are not statistically significant and a methodology which allows the analyst to consider certain lots while excluding others opens the door to all kinds of bias. There will be no simple solution to the problem. The best remedy is for excavators and analysts to work closely. Excavators should, based on cave context, rate each lot on its potential for containing naturally deposited bones so that lots likely to contain non-cultural material can be eliminated before analysis is undertaken. In the end, the best results may be obtained by focusing attention on only those lots that offer particularly good opportunities for providing uncontaminated samples, such as those directly off use-surfaces.

Finally, we have noted that studies of Maya ritual fauna have tended to focus on very restricted samples recovered from special contexts such as burials and caches (Carr, 1985: pp. 126-129; Moholy-Nagy, 1985). As archaeologists and analysts increasingly venture out into "natural places" (Bradley, 2000), they need to adopt the perspective of the ritual specialist who realizes that species naturally associated with these landmarks may be the most likely to have been utilized in ritual.

\section{Acknowledgements}

Fieldwork was carried out while the author was on a Fulbright-Hays Training 
Fellowship from the US Department of Education. The project was financed in part by a National Science Foundation Dissertation Improvement Grant (BNF-8800946). The authors would like to thank Betty Benson for her encouragement in looking more deeply into bats and Kitty Emery for her always constructive critiques of this work.

\section{Conflicts of Interest}

The author declares no conflicts of interest regarding the publication of this paper.

\section{References}

Bernal, I. (1949). Murciélagos. Tlatoani, 3, 95.

Bradley, R. (2000). The Archaeology of Natural Places. London: Routledge.

Brady, J. E. (1989). An Investigation of Maya Ritual Cave Use with Special Reference to Naj Tunich, Peten, Guatemala. PhD Dissertation, Los Angeles, CA: Archaeology Program, University of California.

Brady, J. E., \& Coltman, J. D. (2016). Bats and the Camazotz: Correcting a Century of Mistaken Identity. Latin American Antiquity, 27, 227-237.

https://doi.org/10.7183/1045-6635.27.2.227

Brady, J. E., \& Prufer, K. (1999). Caves and Crystalmancy: Evidence for the Use of Crystals in Ancient Maya Religion. Journal of Anthropological Research, 55, 129-144. https://doi.org/10.1086/jar.55.1.3630980

Brady, J. E., \& Rissolo, D. (2006). A Reappraisal of Ancient Maya Cave Mining. Journal of Anthropological Research, 62, 471-490. https://doi.org/10.3998/jar.0521004.0062.402

Brady, J. E., \& Rodas, I. (1995). Maya Ritual Cave Deposits: Recent Insights from the Cueva de los Quetzales. Institute of Maya Studies Journal, 1, 17-25.

Brady, J. E., Scott, A., Neff, H., \& Glascock, M. (1997). Speleothem Breakage, Movement, Removal and Caching: An Unreported Aspect of Ancient Maya Cave Modification. Geoarchaeology, 12, 725-750. https://doi.org/10.1002/(SICI)1520-6548(199709)12:6<725::AID-GEA10>3.0.CO;2-D

Carr, H. S. (1985). Subsistence and Ceremony: Faunal Utilization in a Late Preclassic Community at Cerros, Belize. In M. Pohl (Ed.), Prehistoric Lowland Maya Environment and Subsistence Economy (pp. 115-132). Papers of the Peabody Museum of Archaeology and Ethnology, Vol. 77, Cambridge: Peabody Museum, Harvard University.

Coe, W. R. (1959). Piedras Negras Archaeology: Artifacts, Caches, and Burials. Philadelphia, PA: The University Museum, University of Pennsylvania.

Coe, W. R. (1990). Excavations in the Great Plaza, North Terrace and North Acropolois of Tikal. Tikal Report No. 14. Philadelphia, PA: The University Museum, University of Pennsylvania.

Cook, G. (1986). Quichean Folk Theology and Southern Maya Supernaturalism. In G. H. Gossen (Ed.), Symbol and Meaning Beyond the Closed Community: Essays in Mesoamerican Ideas (pp. 139-153). Albany: Institute of Mesoamerican Studies, State University of New York, Albany.

Eliade, M. (1958). Patterns in Comparative Religion. New York: Sheed and Ward.

Emery, K. F. (2004) Animals from the Maya Underworld: Reconstructing Elite Maya Ritual at the Cueva de los Quetzales, Guatemala. In S. Jones O'Day, W. Van Neer, \& A. 
Ervynck (Eds.), Behaviour Behind Bones: The Zooarchaeology of Ritual, Religion, Status and Identity (pp. 101-113). Oxford: Oxbow Books.

Fernandez, M. A. (1943). New Discoveries in the Temple of the Sun in Palenque. Dyn, No. 4-5, 55-58.

Halperin, C. T., Garza, S., Prufer, K., \& Brady, J. E. (2003). Caves and Ancient Maya Ritual Use of Jute. Latin American Antiquity, 14, 207-219. https://doi.org/10.2307/3557596

Hamblin, N. L. (1984). Animal Use by the Cozumel Maya. Tucson: University of Arizan Press.

Luther, E. (1974). Faunal Material. In D. M. Pendergast (Ed.), Excavations at Actun Polbilche, Belize (pp. 62-80). Monograph 1. Toranto: Royal Ontario Museum.

Moholy-Nagy, H. (1985). The Social and Ceremonial Uses of Marine Molluscs at Tikal. In M. Pohl (Ed.), Prehistoric Lowland Maya Environment and Subsistence Economy (pp. 147-158). Papers of the Peabody Museum of Archaeology and Ethnology, Vol. 77, Cambridge: Peabody Museum, Harvard University.

Morris, W. F. Jr. (1986). Maya Time Warps. Archaeology, 39, 52-59.

Pendergast, D. M. (1969). The Prehistory of Actun Balam, British Honduras. Art and Archaeology Occasional Paper 16, Toranto: Royal Ontario Museum.

Pendergast, D. M. (1971). Excavations at Eduardo Quiroz Cave, British Honduras (Belize). Art and Archaeology Occasional Paper 21, Toranto: Royal Ontario Museum.

Pendergast, D. M. (1974). Excavations at Actun Polbilche, Belize. Monograph 1. Toranto: Royal Ontario Museum.

Pohl, M. (1983). Maya Ritual Faunas: Vertebrate Remains from Burials, Caches, Caves, and Cenotes in the Maya Lowlands. In R. M. Leventhal, \& A. L. Kolata (Eds.), Civilizations in the Ancient Americas (pp. 55-103). Albuquerque: University of New Mexico Press.

Pollock, H. E. D., \& Ray, C. E. (1957). Notes on Vertebrate Animal Remains from Mayapan. Department of Archaeology, Current Reports No. 41, Washington DC: Carnegie Institution of Washington.

Redfield, R. (1941). The Folk Culture of Yucatan. Chicago: University of Chicago Press.

Ricketson, O. G. Jr., \& Ricketson, E. B. (1937). Uaxactun, Guatemala: Group E 1926-1931. Washington DC: Carnegie Institution of Washington.

Savage, H. G. (1971). Faunal Material. In D. M. Pendergast (Ed.), Excavations at Eduardo Quiroz Cave, British Honduras (Belize) (pp. 78-111). Royal Ontario Museum Art and Archaeology Occasional Paper 21, Toranto.

Scott, A. M. (2012). The Historical Context of the Founding of Maya Cave Archaeology. In J. E. Brady (Ed.), Heart of Earth: Studies in Maya Ritual Cave Use (pp. 9-15). Austin: Association for Mexican Cave Studies.

Smith, A. L. (1950). Uaxactun, Guatemala: Excavations of 1931-1937. Carnegie Institution of Washington Publication 588, Washington DC.

Thompson, J. E. S. (1939). Excavations at San Jose, British Honduras. Washington DC: Carnegie Institution of Washington.

Tozzer, A. M. (1941). Landa's Relacion de las Cosas de Yucatan. Papers of the Peabody Museum of American Archaeology and Ethnology, Vol. XVIII, Cambridge: Harvard University.

Vogt, E. Z. (1969). Zinacantan: A Maya Community in the Highlands of Chiapas. Cambridge, MA: Harvard University Press. 